Journal of Social Sciences (COES\&RJ-JSS)

ISSN (E): 2305-9249 ISSN (P): 2305-9494

Publisher: Centre of Excellence for Scientific \& Research Journalism, COES\&RJ LLC

Online Publication Date: $1^{\text {st }}$ April 2015

Online Issue: Volume 4, Number 2, April 2015

http://www.centreofexcellence.net/J/JSS/JSS Mainpage.htm

\title{
Contextualising the Syrian Crisis against Realism and Security Competition in the $21^{\text {st }}$ Century
}

\author{
Dr. Declan A. Amaraegbu \\ Durham University, United Kingdom
}

\begin{abstract}
The objective of this paper is to promote critical engagement with a wide range of theoretical and empirical issues regarding the applicability and relevance of Realism or Realpolitik in the new realities of today's international politics. It draws on arguments taken from scholars but are reconstructed in a way useful to students of IR. It aims to evaluate the realist claim that international politics revolve around state actors and the pursuit of their national strategic interests in an anarchic international system. To assess this argument, Russian attitude towards the international community's proposal for a resolution to intervene in the Syrian civil war will be reviewed. This will help to determine the applicability and potency of the core assumptions of Realism in today's international politics.

Realism may not be a new thinking, but given that war is a recurrent event in world politics, this paper will establish that the Realist paradigm remains one of the most accurate theories for understanding developments in today's world. This paper argues that as long as lack of global coordination due to individual national security or pride issues remain the bane of the global community, Realism is still relevant in the understanding of international politics in the $21^{\text {st }}$ century.
\end{abstract}

\section{Key Words}

Realpolitik, state- centric, balance of power, system polarity, Self-Help

\section{Citation}

Amaraegbu, Dr. Declan A. (2015); Contextualising the Syrian Crisis against Realism and Security Competition in the $21{ }^{\text {st }}$ Century; Journal of Social Sciences (COES\&RJ-JSS), Vol. 4, No. 2, pp:795-811.

http://dx.doi.org/10.17632/8h5gg8mvjy.1 


\section{Introduction}

Even in the $21^{\text {st }}$ century, decades after World War II and end of cold war, the Realist theory is still a dominant part of the study of International Relations (IR) and it has reared its head in the Syrian civil war. At first glance, the Realist perspective might seem irrelevant in today's international politics, but certainly comes into play - albeit inadvertently - when the Syrian crisis, the role of Russia and the West is analysed.

During the Cold War, scholars and policy makers explained world events and diplomatic relations amongst nation-states through the lens realist theory. However, pessimists believe that the post-cold war international politics has witnessed tremendous transformation and Realism has lost its relevance. With the end of the cold war, the proponents of this cynical viewpoint argue, this 'antiquated' perspective is no longer fully able to satisfactorily explain current international politics due to the globalization of economies that has led to an ever-increasing interdependence between countries and other international organizations. For them, international politics has entered a new phase where nation-states view each other as members of an emergent "International Community" where the likelihood of security competition among great powers is most improbable.

During 15th and 16th centuries, realism or Realpolitik emerged as an influential theoretical paradigm that explains how the international system works. It was only after the cold war that realists, in the words of Guzzini (2001: 111) found themselves under closer scrutiny again. Yet, while its core assumptions has, understandably, been challenged by emerging theoretical perspectives, it is one theoretical framework that has held a central position in the explanation of wide range of issues in international politics in the study of IR and remained useful in the explanation of causes and effects of war in the last five decades..

Hans Morgenthau's 'Politics among nations' and Kenneth Waltz's 'Theory of International Politics' remain the context within which international-relations scholars have based their discourses for much of the post- World War II era. Indeed, some of the concepts they introduced are literally part of contemporary curriculum in any module on International Relations (IR). Steans \& Pettiford (2005: 49) were right when they reminded us that given the condition of anarchy, states have the highest authority in the international system. The concept of 'statism' was not lost on Dunne \& Schmidt (2008: 103) when they argued that the state is pre-eminent actor [while] all other actors in world politics are of lesser significance. What this means is that it is the states that come together to form international organisations and that these organisations do not control the states. The core element of Realism is balance of power derived from the concept of power is relevant and applicable in today's world. Russia's brave opposition to the use of force by the UN in Syria and the compromise that came as a result is a strong pointer to the applicability of Realism in the new realities of the $21^{\text {st }}$ century international politics. This example shows that the UN could never realize its aims of preventing conflicts and maintain world peace on its own without the authorisation of its members, especially the five permanent members of the Security Council due to the realist approach to international politics used by member states.

\section{Conceptual Overview of Realism}

This section seeks to explore theoretical perspectives of Realism and to evaluate its relevance in understanding contemporary issues and developments in world politics. The theoretical framework set forth in this paper presents Realism as a theory of IR, one that does not only highlight the role of sovereign territorial nation-states in international politics but also one that seeks to explain why states act the way they do and emphasizes 


\section{Contextualising the Syrian Crisis......}

the persistent role of sovereign territorial nation-states in international relations .The system of sovereign territorial nation-states, George (1994:72) argued, is sustained against overthrow by the balance of power. Scholars of international relations (Inayatullah and Blaney, 2004: 22; Riggs and Plano, 1988: 1) have argued that the concept of modern sovereignty of nation-states or international system of states dates back to the Westphalia treaty signed in 1648. The Westphalia agreement which is shared by the Realist school provided for the respect of the sovereignty of nation states as protected under international law. The principle gives leaders of sovereign nation-states, the freedom and responsibility to do whatever is necessary to advance the state's interests and survival (Kegley and Wittkopf, 1995: 22).

The Realist paradigm focuses on four cardinal viewpoints: 1 . The international system is anarchic; 2. In the international system, States are the most important actors; 3 . All states within the system are unitary, rational actors and tend to pursue their national interests; and 4. All states are primarily concerned with their survival (Donnelly, 2008:150). As applied, the central view shared by Realist theorists is that international politics takes place within a context of anarchy. Therefore, states must demonstrate that it is strong enough to care for and protect her citizens within the anarchical international system. This perception can be reformulated as the core premise that provide logical fundamental assumptions about state power, national interests and why state actors act the way they do in international politics.

With its emphasis on war, struggle for power and security competition, Realism presupposes that it is states, and not international organizations, that are the key actors and determine what happens in the world (Ray and Kaarbo, 2011: 5). Donnelly (2005: 29) referred to it as the oldest and most used theory of international relations and according to its assumptions, States can, if they choose, control all other actors (Ray and Kaarbo, 2011: 5). The state-centric assumption of Realism (Dunne and Schmidt, 2008: 93) is the argument that as the central actors in international politics. Therefore, Realism is statecentric because of the central and predominant position that states play in this perspective (Ray and Kaarbo, 2011:5). Vasquez (1997:899) has defined it in terms of a set of theories associated with a group of thinkers who emerged just before World War II and who distinguished themselves from idealists (i.e., Wilsonians) on the basis of their belief in the centrality of power for shaping politics, the prevalence of the practices of power politics, and the danger of basing foreign policy on morality or reason rather than interest and power. While the debate over its applicability within today's IR enquiry has been fairly extensive, there has been little dispute regarding the premise on which world politics revolves. The world is composed of nation states with opposing interests hence conflict among them is inescapable.

Kegley \& Wittkopf, (1995: 31) has defined Realism as a paradigm based on the premise that world politics is essentially and unchangeably a struggle among self-interested states for power and position under anarchy, with each competing state pursuing its own strategic interests. In 2011, the U.N. Security Council authorized "all necessary measures" to stop the violence in Libya even when Russia and China abstained from the vote after the Arab League and the African Union requested UN involvement to stop the carnage. But a year later, tensions between Russia and the other permanent members of the Security Council caused the UN to look on while Syrian conflict escalated into full blown civil war. That Russia and China issued a veto of a sanction-less resolution that would authorise the UN to intervene militarily to contain the Syrian violence only confirms that pursuit of states' national interests and the struggle for power define politics at the world stage. 
Ray and Kaarbo (2011:4) noted that realism is a theoretical perspective for understanding IR that emphasizes states as the most important actor in global politics, the anarchical nature of the international system, and the pursuit of power to secure states' interests. USled war against global terrorism, NATO- led multi-state coalition military operation in Libya in 2011, and the US's hegemonic agenda are all evidence that the emergence of the "New World Order" has not diminished the relevance of realism in the new realities of international politics. From a realist perspective, the international political system lacks a recognised central regulatory authority and as such States resort to Self-help in an anarchic world. Self-help, which Dunne and Schmidt (2008: 93) define as the principle of action in an anarchical system where there is no global government is a crucial matter in IR. This principle presupposes that nation-states are responsible for ensuring their survival and wellbeing. In international politics, all state actors function to acquire power since they compete among themselves and which often results in what Hobbes (1985:185) referred to as war of all against all.

Sovereign states always clearly formulate their geopolitical interests and pursue them aggressively. The U.S. military action in Iraq, Afghanistan and in Libya, where the multistate coalition wilfully interpreted UN Security Council resolution to legitimise their military action are points of reference. Since the international system can be said to be in state of anarchy devoid of any central authority, sovereign states remain the principal actors and superpowers compete among themselves on who wield the most power and influence. Diplomacy is most effective when it has a strong military component behind it, so nation-states strive to increase their military capabilities and amass as much resources as possible in order to pursue and protect their strategic national interests. Given that the fundamental features of international politics hardly ever change, State actors do not seem to worry about the moral correctness of their actions. They are not there to conform to some 'absurd' moral expectations, but to advance their national security and other strategic interests. Jackson \& Sorensen (1999: 73) drew attention to the Machiavellian assumption of Realist tradition that political responsibility of the statesman cannot always be in accordance with the principles of Christian ethics.

If morality has a place in international politics, tension between the super-powers would not have prevented the UN Security Council from passing a resolution that would stop the blood-shed and carnage in Syria. As Aron (1996:587) noted, the state is a power only in order to maintain itself side by side with other equally independent powers. Realism is all about power and this power, in practical terms, is defined primarily in terms of economic strength and military might. By nature, nation states, like the "men" who compose them, are selfish, assertive and will even go to war in pursuit of their interests to the detriment of others, sometimes, in violation of international law and without regard to morality. Although Neo-realists acknowledge that states are only self-interested, military interventions almost always cast doubt on the moral justification for such missions.

Since this paper dwells on the currency of Realism in the realities of the new world order, it is important to digress (albeit a bit more) to the events in Libya which took place in 2011 which has some relevance to this discourse. The multi-state coalition military intervention in Libya on March 19, 2011 to implement United Nations Security Council Resolution 1973 gave realists a field day for criticising the moral structures of rules-based international system. Under Muammar Gadhafi, Libya previously pursued nuclear weapons and possessed chemical weapons and ballistic missiles. On 19 December 2003, he announced that Libya would renounce its weapons of mass destruction (WMD) programs and long-range ballistic missiles. He welcomed international inspectors to verify that Tripoli would follow through on its commitment (Arms Control Association, 2014). 
But Gadhafi paid the price of giving up Tripoli's nuclear weapons in 2003. Tripoli's disarmament and integration into international economic institutions proved meaningless. For emphasis, morality does not matter when the vital national interests of great powers are at stake. As we know, the multi-state coalition military operation was reportedly taken in response to events during the Libyan Civil War.

Determined to stop government attacks against civilians, this constituted "crimes against humanity", the multi-state coalition had no intention of turning back on the defence of "ordinary Libyans" who had come under increasing attack from establishment security forces. The Security Council imposed a ban on all flights in Libya's airspace, - a no-fly zone - and tightened sanctions on the Gadhafi regime and its supporters (Department of Public Information, 2011). With the resolution approved, full scale military operations dubbed "Odyssey Dawn" began on March 19 with the deployment of French fighter jets over Libya, firing of more than 110 Tomahawk missiles from American and British ships and submarines and other activities (CNN, 2011). From then till Gadhafi was brutally murdered, the NATO coalition never wavered from its initial declaration of humanitarian rationales. The strategic objective of the campaign was to hurt Gadhafi beyond belief. The coalition forces were to undertake sorties across Libya, destroy everything that indicated the presence of his command and control infrastructures, strike at the heart of the "rogue regime's" military installations, route its air force capabilities, knock out army tanks and vehicles, and effect naval blockade. Indeed, they displayed a capacity to get to their objectives faster, almost unchallenged as Gadhafi's disoriented military faded away once the coalition forces took their rifles off safety.

The moral appropriateness of the Libyan intervention may have been hinged on (a) the just cause argument and (b), the right intention argument. But even both arguments did nothing to answer the ethical questions the intervention raised. The ethical issues raised by the intervention are clear. The interests of the intervening states were more of an explanation than a genuine humanitarian gesture to stop Gadhafi's "murderous madness" against his people:

The attacks will undoubtedly kill civilians, and these will be innocent men, women, and children, Arab and Muslim, killed (again) by the French, the British, and the Americans...Russia and China, who opposed the intervention, abstained on the final Security Council vote, perhaps because they can't imagine an outcome that better suits their interests in the Middle East and Africa (Walzer, 2011).

In the opinion of British Prime Minister, David Cameron, the NATO-led military campaign that ended the regime, 42-year career and life of Muammar Gaddafi was "necessary, legal and right". It was not "right", he said, for the "international community" to stand aside while "this dictator" murders his own people (CNN, 2011). The Prime Minister's thesis has three main effects--it presented the humanitarian argument as a factual justification, it refocused attention on Libya's "narcissistic" leader since 1969, a despot who reportedly backed global terrorism and a bogeyman of the western world who substituted a cult of personality for the rule of law and it brought a renewed attention to the existing World order, an international system replete with hypocrisy and two-faced policies.

Cameron's analysis of the issue paints a picture of a nation where Gadhafi and his goons, armed with their guns, failed to move on from the pernicious fascistic narrative of authoritarian nationalism or absolute political power by state, as justification for extreme evil against the Libyan people. Therefore, the military action was rational, justified and fully in line with the norms of international law and the UN charter; Gadhafi's genocidal 
intent may have been illusory, but his terror was real. He was simply relying on the "just cause" and "right intention" arguments to justify the coalition's "right" decision to stop 'the mad dog of the Middle East's' offensive aggression' against the Libyan population. Therefore, the operation was a strategy intended to isolate and make it hurt for Gadhafi, support the Libyan sovereignty, independence, territorial integrity, and the right of the Libyan people to determine their own future. In his first major speech justifying the military operation in Libya, President Obama said: We knew that if we waited one more day, Benghazi could suffer a massacre that would have reverberated across the region and stained the conscience of the world. It was not in America's national interest to let that happen (Parsons, 2011).

Indeed, Gadhafi had threatened to perpetrate a real bloodbath, a massacre like we saw in Rwanda (Reuters, 2011). But did the casualties approach the magnitude of a Rwandan genocide or serious enough to warrant the firing of "more than 110 Tomahawk missiles from American and British ships and submarines" in one day into Libya that reportedly killed nearly 50 people, including, women, children and clerics (CNN, 2011)? Did the situation constitute a threat to the stability and good functioning of the current international order? Yet, firing missiles from the seas into an inhabited area has grave human rights collaterals. NATO forces were originally mandated to protect civilians only. Yet, protecting civilians apparently did not generate sufficient public support for intervention .In due course, the coalition forces transformed into an instrument of regime change, in coordination with the rebel forces on the ground. Russia accused NATO of abusing the UN resolution authorising military actions by seeking to bring about regime change rather than just protecting civilians (The Guardian, 2011). The Tomahawk missiles, a weapon of choice in the multi-state coalition attacks on far-flung government arms depots, were packed with explosives and it caused massive damage to urban areas and killed many people.

The moral contradiction in Cameron's argument is what Walzer (2000: xi) referred to as chief dilemma of international politics. Nations want to "help" foreign populations stop genocide and oppose tyranny only if the operation serves the interests of the interveners. In May 1994, US President, Bill Clinton signed a Presidential Decision Directive stating that his country can only participate in UN peacekeeping mission if there is an identifiable American interest at stake (Kegley and Wittkopf,1995: 534). Also, the US House of Representatives passed a bill preventing American involvement in countries where no American interests are involved (Polman, 2004: 172). Any wonder the "international community" failed to do the needful in the Rwandan genocide of 1994 ?

Some analysts denounced the military action as a great farce as there was no evidence of the level of threats that warranted such huge military operation in Libya and considered the humanitarian argument a bogus pretext. As Walzer (2011) noted, a military attack of the sort [that happened in Libya] ...is defensible only in the most extreme cases. Rwanda and Darfur, where we didn't intervene, would have qualified. Libya doesn't. Walzer (2000:107) argued that interventions are only justifiable if they are in response to atrocities that shock the moral conscience of mankind. According to Destexhe (1994: 3-4), over 800,000 Tutsi and moderate Hutu were killed in the Rwandan genocide. Yet, the international community absolutely failed to prevent and stop what was a clear case of genocide and massacre in that country in 1994. While a combination of interconnected and complex factors may have conspired to prevent international intervention, the "shadow of Somalia" (Barnett 2002: 21), the grave misgivings of an American public weary of war since Somalia and Rwanda's negligible geopolitical importance were important dynamics. However, there is debate about whether the infringement of Libyan state sovereignty 
reflected the higher principles of stopping the "mad dog" from decimating the Libyan population or whether Qaddafi was being bombed for reasons other than humanitarian concerns.

The realist thinking that much of nation-states' behaviours in international politics are influenced by human nature was given perspective by Hans Morgenthau. He structured the Realist theory on the basis of six principles which are summarised as follows: 1. politics is governed by objective laws that are rooted in human nature; 2 . the concept of interest defined in terms of power; 3 . Realism assumes that its key concept of interest defined as power is an objective category which is universally valid; 4 . Realism rejects the notion that universal moral principles should be applied to the actions of states in the pursuit of their national interests.; 5. Realism emphasises the importance of the self-interest of nation states as opposed to moral laws that govern the universe; 6. Political realism recognizes the pluralistic view of human nature but maintain the autonomy of the political realm. "How does this policy affect the power of the nation?" he asked. The Realist tradition is based on a pluralistic conception of human nature. A man who was nothing but "political man" would be a beast, for he would be completely lacking in moral restraints. But, in order to develop an autonomous theory of political behaviour, "political man" must be abstracted from other aspects of human nature (Morgantheau, 1978: 4-15).

Morgenthau's depiction of the international system may not reflect what other theoretical paradigms think, but on the basis of the subject of the present exercise, that is, the Syrian crisis, it could represent a useful description of international politics since it is based on the assumptions about human nature:

The statesman must think in terms of the national interest, conceived as power among other powers. The popular mind, unaware of the fine distinctions of the statesman's thinking, reasons more often than not in the simple moralistic and legalistic terms of absolute good and absolute evil (Morgantheau, 1978, 165).

From the Realist perspective, human nature may be imbued with benevolence but like the nation-state, survival remains the topmost priority. The anarchy of the international system makes it impossible for nation-states to maintain a generous or compassionate international image but to ensure that sufficient power is acquired to pursue their strategic interests necessary for survival. In the tragic eventuality that a nation-state is unable to muster the delicate mix of military capability and economic power required to remain relevant, the only other solution is an alliance with more powerful nations for logistical and intelligence support. The actions in international politics are primarily determined by human nature, and the universal desire to acquire maximum power is one of objective laws that have their roots in human nature (Morgenthau, 1985:4). Man has operated in a state of nature where no law existed above him to prevent him from acting according to a specified set of rules. The parameters were defined by Hobbes (1985:185): the state of nature has shaped human nature which is characterized by competition, diffidence and glory amongst humans.

Since World War II, realism has proved to offer explanation to much of contemporary issues and developments in world politics and continues to offer prescriptions of state behaviour. But its achievements do not mean an absence of criticisms. Opposing theoretical paradigms reject Realist claims that the international system is essentially defined by the absence of a central authority and that nation-states can defend themselves and survive only through power. Constructivism, for example has challenged the Realist view that anarchy is inevitable in our world. As Wendt (1992:395) argued, self-help and power politics are institutions, not essential features of anarchy. Anarchy is what states make of it, he argued. Realism, from their perspective, is a weak IR theory that is unable 
to provide a conceptual framework for the analysis of the relationships amongst nationstates on its own. International structure, constructivists contend, consists fundamentally in shared knowledge, and this affects not only state behaviour, but state identities and interests as well (Wendt, 1999:31). Anarchy, they point out, is not an unavoidable feature of international reality (Zehfuss, 2002:4). But in the midst of all the criticisms, there is little doubt that state's foreign policies are guided by the logic of the national interests, usually defined in terms of survival, security and power.

\section{Realist Theory and Russia's compromise on the Syrian Civil War}

As the UN opened a series of events to observe the 20th anniversary of the 1994 Rwandan genocide on Thursday 27 February, 2014, UN Secretary General, Ban Ki-moon, derided the international community's failure to implement the lessons learnt from the Rwandan genocide. Indeed, the Rwandan shame exposed the fragility of the "International Community" and amounted to a profound, crisis-prone repudiation of the global community project. Consequently, the genocide of Rwanda became the most significant interrogation of the weak, pathetic, imbalanced "International Community" project. In a statement that was indirectly meant to counsel the international community against placing national interest above morality, he said: Our collective failure to prevent atrocities in Syria over the past three years is a shameful indictment of the international community (The Nation, 2014).But human rights or ideological preferences rarely compel states to act. This position is based on the view that conflicting national interests in the guise of compassion for the suffering victims of humanitarian emergencies and a desire to help them (Dewey, 2004), sustain the anarchic international system.

For realists, a nation-state's position in the international status hierarchy is dependent upon military power and the concentration of power influences a nation- state's foreign policy. However, superior military capabilities alone do not necessarily translate to superior status or respect but states are motivated to act by their desire to perpetuate, protect, or increase its influence in relation to other states. As Ray and Kaarbo (2011: 5) noted, it is the maximization of power that is in a state's interest. 'State's Interest' is of relevance to us in the present exercise. Our focus is on Russia and the question this section seeks to address is: to what extent does Russia's compromise in the Syrian crisis prove that Realism is still very much applicable in the realities of today's international politics? But the Syrian case is quite interesting since Russia did not show the same level of enthusiasm to stop military action in Libya in 2011. Russia had the right to defend Syria against unacceptable western intervention because events in Syria did not conform to international law.

A country's territorial integrity and political independence takes precedence over protecting the population. Without UN Security Council authorisation, no amount of violations of international law or even genocidal acts is sufficient enough to warrant intervention in another country. But powerful nations sometimes breach international laws in pursuit of their strategic interests. The closer analogy, one that appears at some level to influence this thinking, was the U.S. invasion of Iraq. That was done without U.N. authorisation by what U.S state department called the coalition of the willing that that included some 30 nations (BBC, 2003). By any international norm, U.S invasion of Iraq was lawless and a serious challenge to the rule of law around the world, President Bush's flimsy excuses notwithstanding. He sought for U.N. authorization, did not get it but proceeded anyway. If the Americans could flex their muscle in Iraq, a country more than 7,000 miles from its shores to demonstrate its power, then Russia could flex its muscles to protect Syria, a country with which it shares deep historic strategic ties. Russia saved 
President Bashar al-Assad's regime, repeatedly blocked U.N. attempts to condemn him and supplied arms for the government side in a civil war in which over 100,000 people died. In a statement credited to Russia's Deputy Foreign Minister Gennady Gatilov, Moscow warned NATO and Gulf Arab leaders to keep out of the Syrian conflict. In our contacts with partners in NATO and in the region, he said, we are calling on them not to seek pretexts for carrying out a military scenario or to introduce initiatives such as humanitarian corridors or buffer zones (Reuters, 2012). Those comments drew censure from the west, which accused Russia of being an apologist for Assad's brutal massacre of civilians after mass protests that almost toppled his government.

But more importantly, with the Russians, there are certain things here beyond the genuine effort against the western unacceptable breach of international law, which help us in understand their position. Russia, according to the European Commission (2013), has significant trade relations with Syria, with exports to Syria worth $\$ 1.1$ billion in 2010 and investments in the country worth $\$ 19.4$ billion in 2009. The Syrian crisis and the compromises by the international community solidify Realism's longstanding reputation as an explanatory tool for analysing international politics and expose the conflicting national interests that influence nation-states' foreign policy. The crisis that later metamorphosed into civil in Syria began in 2011 with the overwhelmingly Sunni Muslim rebels trying to oust President Bashar al- Assad's government.

Indeed, the Syrian National Council (SNC), a coalition of Syrian opposition groups was made up of a wide variety of political groups, Islamist groups, exiled dissidents, armed militants, grassroots activists and Al-Nusra Front (ANF), an Al-Qaeda sympathiser that has been designated as a terrorist organisation by the United Kingdom (Fox News, 2013), United States (Al Jazeera, 2012), Australia (ABC News, 2013) and the UN (Al Jazeera, 2013). The objectives of the SNC included: Ensuring absolute national sovereignty and independence for Syria, protecting the Syrian people, preserving the unity of the country and its cities, overthrowing the regime, dismantling the security forces, and holding responsible parties accountable for crimes against the Syrian people, not engaging in any dialogue or negotiations with the regime, and upholding the opposition's commitment to a civil, democratic Syria (BBC, 2013). But the pro-Western SNC that rode on the wave of months of deadly protests to topple a Kremlin-backed Assad's Ba'athist regime was running against the clock to actually effect the regime change that was being demanded for in an ideologically splintered Syria.

Russia, Syria's closest Middle Eastern ally, played a tactical role in the resolution of the crisis in favour of Assad's government due to the special relationship both countries enjoy. In alliance with China, Russia had on October 4 2011, used its position as a permanent member of the UN Security Council to block drafts of a Franco-British sponsored UN resolutions that would permit international military intervention that would have ousted the Assad regime. Indeed, international organisations, like the UN are attributed power to constrain states and to have interests in their own right (Kolodziej, 2005: 156), but the Realist theory perceives state actors as the most important actors in the international system. Therefore, international organisations like the UN, Hough (2004: 3) wrote, are mere alliances of convenience between states. International organisations are unable to impose supranational authority sovereign on nation-states. Realists perceive them as the creations of the most powerful nation-states through which they can perpetuate their power or strengthen their bargain on world events.

From a realist perspective, Russia's effort to frustrate UN resolution to punish the 'recalcitrant' Assad regime was a power move. International organisations, like the UN, the realist paradigm assumes, only serve as arenas for acting out power relationships 
(Mearsheimer, 1995: 340). In order to get an analytical understanding of the whole situation, it is necessary to note that Russia's opposition to UN proposed sanction derive from Syria's strategic dependency to Russia. Syria is the top Middle Eastern recipient of Russian military aid, with majority of military hardware imported from Russia. As Kolodziej (2005:130) noted, in order to stay competitive and survive in a violent world, states must continuously invest in development of their military forces, weaponry, and alliances. It had nothing to do with Assad's personality or the nature of Syria's political system. Russia also chanced in on the growing anti-western sentiments in the Middle East to assert its authority.

In a news report by Syrian Arab News Agency (SANA), Sergei Lavrov, Russian Foreign Minister devised a language to serve as the basis for possible diplomatic dialogue outlining a constructive response, including Syria's readiness to relinquish its chemical weapons stockpile and support for political reforms that would meet the aspirations of Syrian people. Pressures, he suggested, have to be practiced on the two Syrian sides to guarantee resumption of negotiations to realize the aspired solution. Crisis in Syria, he concluded, led to changing [the] country into a stronghold for the extremists and terrorists from different regions of the world (SANA, 2014).

For him, the international community would do well to put aside rhetoric and geopolitical considerations . Rather, priority would be to de-escalate the tension as swiftly as possible including the start of the constitutional reform process with the participation and full consideration of the opinions of all the Syrian ideological groups. Admittedly, he acknowledged that the Syrians who protest against President Assad may have been motivated by concerns for freedom, dignity, social justice, basic human rights, corruption and despotic tendencies in his Ba'athist government. But he said the groups and individuals calling for regime change in Syria may be merely replacing a compassionate ruler with a fractious and deeply ideologically divided opposition. He identified situational parallel with Libya where regime collapse prepared the ground for the emergence of tribes and clans with roguish fundamentalist elements threatening international peace.

It is not in the interests of anyone to send messages to the opposition in Syria or elsewhere that if you reject all reasonable offers we will come and help you as we did in Libya. The [Syrian] situation does not present a threat to international peace and security. Syria is a very important country in the Middle East and destabilizing Syria would have repercussions far beyond its borders (Bloomberg, 2011).

Interest. That was the central point of Lavrov's speech but the strategic perspective from which he spoke derived from recent history. He recalled the West's violation of UN resolutions on Libya. In 2011, the UN resolution that allowed NATO to establish a no-fly zone in Libya to protect civilians that were being mercilessly attacked by Muammar Gaddafi's forces was misjudged by the west. The NATO forces quickly got enmeshed in the civil war and helped the revolutionaries seize power and kill Gaddafi. As a consequence of this, Moscow had doubts that the 'rules of engagement' that maybe contained in a UN resolution on Syria will be honoured by the west. Russia's strategic ties to Syria runs deep. It does not matter if we approve or disapprove of what nation-states say and do, but we examine what they say and do in order to understand their behaviour. Extensive trade and military interests that go back to the Soviet era is the reason why Russia is unwavering in its support for the Assad's regime in the face of the antigovernment revolt in Syria.

The eloquent simplicity of the foreign Minister's point is applaudable but it cautiously exposes all the lingering complexities of balance of power and/or system polarity in 
modern International politics. Russia's relations with the West have always been filled with mutual distrust since the 1991 breakup of the Soviet Union. Deeply embarrassed by its drop from superpower status after the collapse of the Soviet Union, and emboldened by Europe's dependence on its energy sources, it was a matter of time and chance before Russia found a way to retaliate. Russia is a permanent member the UN Security Council, who has shown pragmatic flexibility in doing what it takes to project itself as a strong player on the international stage. Russia knows how to use power, with severity when it deems that necessary. Like the West, Russia uses its vast military and economic capabilities to purse its strategic interests. They all think entirely in terms of the system of states. Although this system can be amoral, nation-states employ rhetoric of peace as well as rhetoric of utilitarianism during their power plays and disputes.

In an anarchic world, IR theorists of the realist persuasion would argue, international politics, like all politics, is a struggle for power (Morgenthau, 1954:25). The wider point here is that Power, in the Realist tradition, is understood in terms of military and economic resources necessary to hurt or coerce other state actors. With this power, superpowers apply diplomatic and sometimes coercive tactics if needs be, to pursue their national interests or at least avoid anything that could harm their national interests. In some ways, the platform Lavrov chose for his political argument and the emotional message he gave the world about Russia's preference for a negotiated end to conflict said it all. His speech gave the impression of balance, but it seemed more to reflect Russia's genuine anger about what it perceives as the West's hypocrisy and its overbearing meddlesomeness in Syrian affairs. His remarks also showed what many observers have thought: Russia's deep involvement and strong personal sentiments about the Syrian crisis, which it blamed on the West. But he could not offer a unique take on the strange, unfriendly relationship between Russia and USA, two nations which are similar to one another than they care to admit but have been at least partially defined by their contests.

Lavrov's diplomatic logic was remarkable but it was, to all intents and purposes, a reflection of Russia's global race agenda in diplomatic garb. In practical terms, Assad's handling of the crisis may be far from convincing but Russia would not give up easily on its most important ally in the Middle East. Syria is host to Russia's only Mediterranean naval facility for its Black Sea Fleet at its port of Tartus. Russia knew that any military operation in Syria had serious ramifications for its strategic and geopolitical interests. In the most telling sign of Russia's support for the Assad regime, Lavrov counselled that "the [Syrian] situation does not present a threat to international peace and security". For those routing for military action, he advised, "Syria is a very important country in the Middle East and destabilizing Syria would have repercussions far beyond its borders"- but the point was clear. For Realists, Russia's proposition for a diplomatic solution was in Russia's interest, and Russia would do anything to save the Assad regime regardless of its human rights records and ideological preferences. In the same way, the reaction of the West and United States in their decision to support a military action to punish the Assad regime was far from genuine humanitarian concerns but more to do with entrenched interests and the maximization of power and influence within the region.

In a historical context, both countries have shared a close relationship. The relation of former USSR and Syria was initiated with a secret agreement signed on February 10, 1946, just before the declaration of independence of Syria. That agreement prescribed the provision of diplomatic and political support of USSR to Syria in the international arena and the Soviet military help for the foundation of Syria's national army (Aghayev, 2012:2067). In 1956 Syria followed Egypt in acquiring arms from the Soviet Union, and the Suez War accelerated a multiplication of ties between Syria and the Soviet Union- 
ties closely associated with the increase in power and influence of the Ba'ath Party (Mansfield, 2010:293).

This background is significant in the context of this paper's reflections on the charged Realism debate, particularly its applicability and relevance in contemporary international politics. Several aspects related to the Syrian conflict demonstrate Realism's relevance to global politics in the 21st century. In the Syrian case, two permanent members of the UN security council frustrated UN attempts to intervene militarily to defeat President Bashar al-Assad. Russia and China vetoed three Security Council resolutions that would have contained Assad's regime and threatened it with sanctions. Indeed, they blocked UN's resolution to impose measures under Chapter VII of the UN Charter that would have come with military action or economic sanctions (BBC, 2014). The behaviour of states, realists argue, is interpreted in terms of the pursuit of power (Wight, 1995: 17). Powerful states favour mending relations with nation -states with strong military capabilities and economic strength- the Russias and Chinas of this world - at the expense of ones with less economic and military might. Nation states are concerned about prestige, power, interests, and capabilities, not necessarily values or intentions.

Russia has been striving to regain international prestige after the collapse of former USSR. The connection between prestige and power in international politics has been established:

In international relations, prestige is the functional equivalent of the role of authority in domestic politics...Authority (or prestige) is 'the probability that a command with a given specific content will be obeyed by a given group of persons.' Thus, both power and prestige function to ensure that the lesser states in the system will obey the commands of the dominant state or states...in short, numerous factors, including respect and common interest, underlie the prestige of a state and the legitimacy of its rule (Gilpin,1981:30).

Prestige is a critical element in nation-states' quest for international credibility. Implicit and explicit arguments may have been advanced to explain Russia's foreign policy in Syria, there is a general consensus that, if one looks at Russia's foreign policy in general, one finds a much more self-protective and assertive Russia. The country's behaviour in Syria seems to reinforce this ambition. It made serious effort to boost its international image by trying to integrate itself as part of the world powers and also by engaging with the west on the way forward for Syria. The Russian proposal to get the Assad regime to rid Aleppo of chemical weapons did not only draw attention to its power status but also gained immediate pull as it became the framework for diplomatic resolution of the crisis as at September 10 2013. The west welcomed it as being in the interests of all interested parties.

Russia's focus in the Syrian crisis was its national security interests. Understandably, it desperately wanted the situation to develop in a manner suitable to its interests. To achieve this, it was either President Assad remained in power or his regime's ouster would come by way of a negotiated exit, as opposed to a forced removal. This is the strategic calculation that was at the heart of Russia's decision to veto the various UN resolutions that would have led to Assad's forceful removal from power. Syria's uprising offered the possibility of a strategic depletion of Russia's influence in the Middle East. Its international prestige would be weakened by the collapse of Assad's regime, its single Arab ally and a vital link to the Arab world.

To end this section, it is important to cite the remarks of Vladimir Putin, Russia's President, in an unprecedented reaching out to the 'American people and their political leaders' regarding the 'events surrounding Syria'. In an interesting and somewhat emotional communication, he wrote, among other things: 
The potential strike by the United States against Syria, despite strong opposition from many countries and major political and religious leaders, including the pope, will result in more innocent victims and escalation, potentially spreading the conflict far beyond Syria's borders. A strike would increase violence and unleash a new wave of terrorism. It could undermine multilateral efforts to resolve the Iranian nuclear problem and the Israeli-Palestinian conflict and further destabilize the Middle East and North Africa. It could throw the entire system of international law and order out of balance.... Syria is not witnessing a battle for democracy, but an armed conflict between government and opposition in a multi-religious country. There are few champions of democracy in Syria. But there are more than enough Al-Qaeda fighters and extremists of all stripes battling the government ... We must stop using the language of force and return to the path of civilized diplomatic and political settlement...If we can avoid force against Syria, this will improve the atmosphere in international affairs and strengthen mutual trust. It will be our shared success and open the door to cooperation on other critical issues (Putin, 2013).

Coated in diplomatic refinements, Putin used the platform to dissuade the American authorities from any military action against the Assad regime, Russia's most important ally in the Middle East and North Africa. In this author's view, Putin put the case against 'potential strike by the United States against Syria' in a succinct, compelling and simply brilliant manner. Putin had said that Russia was in favour of 'peaceful dialogue' that would enable 'Syrians to develop a compromise plan for their own future' and declared that Russia was 'not protecting the Syrian government but international law'. President Bashar al-Assad knew that international law prohibits the use of chemical weapons and knew that its use will substantially increase the likelihood of collective international military action against his government. For liberal internationalists, the only issue that would justify international military action in Syria is the use of chemical weapons. Therefore, it was difficult for the West to change what was an acknowledged international norm. But, as logical as that may seem, Russia's advocacy for diplomatic or political solution was more about safeguarding and expanding its international prestige and strategic geopolitical interests more than anything else. It would be harder for Putin to have been clearer about what his country's priorities were, or that for Russia, military action in Syria was 'unacceptable under the UN Charter and would constitute an act of aggression'. Therefore, considering the advantages of the Russian-brokered compromise on the civil war, President Putin and his country gained substantial political capital from being able to frustrate western-inspired military action against an ally than from making efforts to protect it after military strikes are launched.

\section{Conclusion}

The position that helps the realist paradigm to find its way through the terrain of IR is the concept of interest in terms of power. It is in this concept that the link between the logic in trying to understand Realism and its relevance in the international system as it currently exists is located. On this note, the assumption is that world leaders and statesmen act in the international arena in terms of interest defined as power, and President Vladimir Putin's application of power in the Syrian crisis strongly reinforces that hypothesis. The concept of national interest was a central, if not dominant, part of the Syria discourse. In the literature, journalism and politics of the "International Community", each nation exhibits an obsession with furthering its national interest in global affairs. "International 
Community" makes sense to world leaders only as a platform to advance international prestige and pursue their specific national interests.

While arguments on the applicability of Realism in contemporary international politics differ extensively, it seems only reasonable to have an opinion. It is on this basis that this study has provided an analysis that engaged the Realist claims and its relevance in the realities of our "new World Order" based on knowledge and thoughtful analysis of the Syrian crisis. This paper has critically examined the Realist theory and measured its claims in respect to the international system as it currently exists (and there is no serious indication that the international system as it currently exists will change any time soon). It has demonstrated that the Realist approach still influences inter-state relations focusing on national interests and balance of power. As shown in the text, states set their foreign policies and pursue them passionately even if their interests are contrary to the interests of others.

For Realists, universal international organizations like the UN are not state actors, and powerful state actors crate these organisations and use them as platforms to increase their international prestige and negotiate their share of global power. The basic nature of interstate relations hardly ever changes. The most fundamental aspect of this unchanging reality is the anarchic nature of the international system. Putin (2013) suggested how this reality can be overcome or managed: we need to use the UN Security Council and believe that preserving law and order in today's complex and turbulent world is one of the few ways to keep international relations from sliding into chaos. But the power to veto Security Council decisions by permanent members was enshrined in the United Nations Charter. Given the influence of Realism in international politics, there is nothing the UN could have done to save Syrians from 'the scourge of war' because Russia and China vetoed UN resolution for military action. The civil war in Syria lasted for such a long time due to the contrasting interests of UN Security Council permanent members.

One of the explanations for Moscow's support for the Assad regime is anchored on its fear of the proliferation of extremist Muslim groups and of state collapse:

Mercenaries from Arab countries fighting [in Syria], and hundreds of militants from Western countries and even Russia, are an issue of our deep concern. Might they not return to our countries with experience acquired in Syria? After all, after fighting in Libya, extremists moved on to Mali. This threatens us all (Putin, 2013).

This paper is not interested in the contested, contending accounts and official explanations of Russia's role in the Syrian crisis, or even questions pertaining to whether diplomatic solution was in the best interest of Syria and Syrians. At minimum, we ought to agree that Russia was also concerned about what state collapse that forcible regime change in Syria may bring. President Vladimir Putin's application of power was, above all, convenient and profitable for Russia. And all the logic that informed the Russia-brokered peace talks to end the increasingly grim civil war in Syria made eminent sense, finally, mostly from the prism of Russia's interests.

Russia's anxiety can be traced to the memory of Chechnya's secession conflict, an event in the country's history. The second Chechen War broke out in October 1999. The Chechen capital of Grozny was captured of in February 2000, the Ichkerian regime fell and Russian authorities presented the war in Chechnya as a crusade against terrorism and an ultimate attempt to avoid the secession of Chechnya from the Russian Federation (Global Security, 2014). No doubt, the collapse of Syria will hurt Russia's pride and geopolitical interests hence it stuck with the realist principles of self-interest, state survival and balancing of power. 
References

ABC News (2013). Australian Government lists anti-Assad Syrian group as terrorist organisation. Available online at: http://www.abc.net.au/news/2013-0629/australia-lists-syrian-group-as-terrorist-organisation/4789476.Accessed on $05 / 03 / 14$

Aghayev, E (2012). Historical Background and the Present State of the Russian Syrian Relations. European Researcher, 35 (11-3); Pp 2066-70

Al Jazeera (2012). US blacklists Syrian rebel group al-Nusra. Available online at: http://www.aljazeera.com/news/middleeast/2012/12/2012121117048117723.html . Accessed on 05/03/14

Al Jazeera (2013). UN blacklists Syria's al-Nusra Front. Available online at: http://www.aljazeera.com/news/americas/2013/05/201353021594299298.html.A ccessed on 05/03/14

Arms Control Association, (2014). Chronology of Libya's Disarmament and Relations with the United States. Available online at: http://www.armscontrol.org/factsheets/LibyaChronology. Accessed on 24/3/14

Aron, R (1966). Peace and War: A Theory of International Relations. New York: Doubleday.

Barnett, M (2002). Eyewitness to a genocide: The United Nations and Rwanda. London: Cornell University

BBC (2003). US names 'coalition of the willing'. Available online at: http://news.bbc.co.uk/1/hi/world/americas/2862343.stm. Accessed on 24/3/14

BBC (2013). Syria crisis: Guide to armed and political opposition. Available online at: http://www.bbc.co.uk/news/world-middle-east-15798218.Accessed on 05/03/14

BBC, (2014). Syria crisis: Russia blocks UN statement on Aleppo attacks. Available online at: http://www.bbc.co.uk/news/world-middle-east-25663616. Accessed on $20 / 2 / 14$

Bloomberg (2011). Russia Warns U.S., NATO Against Military Aid to Syria Protests After Libya. Available online at: http://www.bloomberg.com/news/2011-0601/russia-warns-u-s-nato-against-military-aid-to-syria-protests-after-libya.html. Accessed on 24/02/14

CNN (2011). Gunfire, explosions heard in Tripoli. Available online at: http://edition.cnn.com/2011/WORLD/africa/03/19/libya.civil.war/. Accessed on 27/02/14

Department of Public Information (2011). Security Council Approves 'No-Fly Zone' over Libya, Authorizing 'All Necessary Measures' To Protect Civilians in Libya, by a Vote of Ten For, None Against, with Five Abstentions". Available online at: http://www.un.org/News/Press/docs/2011/sc10200.doc.htm. Accessed on $27 / 02 / 14$

Destexhe, A (1994). The Third Genocide. Foreign Policy, 97 Pp.3-17.

Dewey, A (2004). Motives for Humanitarian Intervention. Remarks to the International Affairs Symposium Lewis and Clark College, Portland, Oregon April 5. Available online at: http://2001-2009.state.gov/g/prm/rls/37930.htm. Accessed on 10/03/14

Donnelly, J (2008). "The Ethics of Realism", in Reus-Smit, C and Snidal, D (eds.), The Oxford Handbook of International Relations, Oxford: Oxford University Press. 
Dunne, T. and Schmidt, B. C. (2008). 'Realism' in Baylis, J., Smith, S. and Owens, P. (eds), The Globalization of World Politics: An Introduction to International Relations, 4th edition, Oxford: Oxford University Press

European Commission (2013). Syria: EU Bilateral Trade and Trade with the World. Available online at: http://trade.ec.europa.eu/doclib/docs/2006/september/tradoc_113451.pdf.Accesse d on $10 / 03 / 14$

Fox News (2013). Britain bans Syria's al-Qaida-linked Nusra Front on terrorism grounds. Available online at: http://www.foxnews.com/world/2013/07/19/britainbans-syria-al-qaida-linked-nusra-front-on-terrorism-grounds/. Accessed on $05 / 03 / 14$

George, J (1994). Discourses of Global Politics: A Critical (Re) Introduction to International Relations. Boulder. Lynne Rienner Publishers, Inc.

Gilpin, R (1981). War and Change in World Politics. Cambridge:

Cambridge University Press

Global Security (2014). Second Chechnya War - 1999-2006. Available online at: http://www.globalsecurity.org/military/world/war/chechnya2.htm.Accessed on $08 / 4 / 14$

Guzzini, S (2001). The Different Worlds of Realism in International Relations.In Millennium: Journal of International Studies, 30 (1). pp. 111 - 121

Hobbes, T (1985). Leviathan. London: Penguin Classics

Hough, P (2004). Understanding Global Security. London. Routledge.

Inayatullah, N. and Blaney, D (2004). International Relations and the Problem of Difference. New York. Routledge

Jackson, R and Sorensen, G (1999). Introduction to International Relations: Theories and Approaches. Oxford: Oxford University Press

Kegley, C. and Wittkopf, E (1995). World Politics: Trend and Transformation. $5^{\text {th }}$ Edition. New York. St. Martin's Press

Kolodziej, E (2005). Security and International Relations. Cambridge. Cambridge University Press

Mansfiedl, P (2010). A History of the Middle East.3rd edition. London: Penguin

Mearsheimer, J (1995). The False Promise of International Institutions. In Brown, M., Lynn-Jones, S., and Miller, S. (ed.) The Perils of Anarchy: Contemporary Realism and International Security. Cambridge; MIT Press

Morgenthau, H (1954). Politics among Nations: The Struggle for Power and Peace, 2nd ed., New York: Alfred A. Knopf.

- (1978). Politics Among Nations: The Struggle for Power and Peace, $5^{\text {th }}$ Revised ed, New York: Alfred A. Knopf.

- (1985). Politics Among Nations, The struggle for Power and Peace” (6th ed.), New York: McGraw-Hill

Parsons, C (2011). Obama defends military campaign in Libya. Los Angeles Times. Available online at: http://articles.latimes.com/2011/mar/28/news/la-pn-obamalibya-web-20110329. Accessed on 04/4/14

Polman, L (2004). We Did Nothing: Why the Truth Doesn’t Always Come Out When the UN Goes In. London; Penguin Books

Putin, V (2013). A Plea for Caution from Russia: What Putin Has to Say to 
Americans about Syria. The New York Times. Available online at: http://www.nytimes.com/2013/09/12/opinion/putin-plea-for-caution-from-russiaon-syria.html? r=0.Accessed on 07/04/14

Ray, J. L and Kaarbo,J (2011). Global Politics.10 ${ }^{\text {th }}$ Edition. Wadsworth: Cengage Learning

Reuters (2012). Syria Crisis: Russia Tells NATO To Stay Away From Syria.Avilable online at: http://www.huffingtonpost.com/2012/10/02/syria-russianato_n_1931707.html. Accessed on 27/3/14

Riggs, R. and Plano, J (1988). The United Nations: International Organization and World Politics. Pacific Grove. Brooks/Cole Publishing Company.

Syrian Arab News Agency (SANA) (2014). Lavrov: International efforts should be unified to solve crisis in Syria. Available online at: http://sana.sy/eng/21/2014/02/01/525497.htm.Accessed on 13/03/14

Steans, J. and Pettiford, L. (2005). Introduction to International Relations: Perspectives and Themes, Harlow: Pearson Education Limited

The Guardian (2011). NATO to end Libya campaign on 31 October. Available online at: http://www.theguardian.com/world/2011/oct/22/nato-end-libya-31-october. Accessed on 17/3/14

The Nation (2014). UN marks Rwandan genocide anniversary. Available online at: http://thenationonlineng.net/new/un-marks-rwandan-genocideanniversary/.Accessed on 28/02/14

Vasquez, J.A. (1997). The realist paradigm and degenerative versus progressive research programs: an appraisal of neotraditional research on Waltz's balancing proposition. American Political Science Review, 91 (4), Pp 899-912.

Walzer, M (2000). Just and Unjust Wars, 3rd ed. New York: Basic Books

Walzer, M (2011). The Case Against Our Attack on Libya. New Republic. Available online at: http://www.newrepublic.com/article/world/85509/the-case-against-ourattack-libya. Accessed on 27/02/14

Wendt, A (1992). Anarchy is what states make of it: The social construction of power politics. International Organization, 46 (2), Pp. 391-425

Wendt, A (1999). Social Theory of International Politics. Cambridge: Cambridge University Press

Wight, M (1995). Power Politics. London: Leicester University Press

Zehfuss, M (2002). Constructivism in International Relations: The politics of realty. Cambridge: Cambridge University Press 